\title{
Analysis of perceptions of auditors/chartered accountants' on selected Indian accounting standards
}

\author{
Viswanathan Bharathan ${ }^{1 *}$, Robinson Joseph ${ }^{2}$, Philip Thomas ${ }^{3}$, E. Sambasivan ${ }^{4}$ \\ ${ }^{I}$ Ras Al Khaimah Women's College, HCT, Ras Al Khaimah, UAE \\ ${ }^{2}$ Skyline University College, University City of Sharjah, UAE \\ ${ }^{3}$ Al-Dar University College, Dubai, UAE \\ ${ }^{4}$ SRM University, Chennai,Tamil Nadu, India \\ *Corresponding author E-mail: vbharathan@gmail.com
}

Copyright $\odot 2015$ Dr.Viswanathan Bharathan et al. This is an open access article distributed under the Creative Commons Attribution License, which permits unrestricted use, distribution, and reproduction in any medium, provided the original work is properly cited.

\begin{abstract}
Indian accounting standards are not only principle based but also based on users' perceived ethical notions on professional ethics and compliance with professional code of conduct that are issued by the Institute of Chartered Accountants of India (ICAI).Codes of conduct for accountants give guidelines for proper behavior in the profession. The present study attempts to understand the perceptions of practicing auditors and professional Chartered Accountants (CAs) on the Indian accounting Standards and adherence to the professional code of conduct issued by the ICAI. The study is based on a survey conducted among a sample of qualified CAs. On the basis of the findings, the study concluded that ethical accounting standards are fundamentally necessary for accountants to produce quality financial reports free from material misstatements.
\end{abstract}

Keywords: Accounting Standards; Auditor's Perception; Code of Conduct; Ethical Code; Professional and Practicing Accountants.

\section{Introduction}

The move towards harmonization of Indian accounting standards with IFRS, could be well served, if the implementation and application aspects of the Indian accounting standards are not only principle based but also based on users' perceived ethical notions on professional ethics and compliance with professional code of conduct that are issued by the Institute of Chartered Accountants of India (ICAI).Codes of conduct for accountants give guidelines for proper behaviour in the profession. The present study attempts to understand the perceptions of practicing auditors and professional Chartered Accountants (CAs) on the Indian accounting Standards and adherence to the professional code of conduct issued by the ICAI. The study is based on a survey conducted among a sample of qualified CAs mainly located in Tamil Nadu, India.

\subsection{Need for the study}

The present study attempts to respond to this need, taking both practicing Auditors and professional accountants who are Chartered Accountants (CAs) as study samples. In spite of several of the above researches conducted, where most of them conducted in the western countries, but not many studies could be referred to as related to Indian accounting scenario. Hence, the present study attempted to understand the first-hand opinion of practicing auditors and professional chartered accountants on the level of acceptance and adherence to the Indian Accounting Standards by corporates and client business firms and the extent to which the work values of professional work-ethics is followed and how independent variables such as professional commitments and professional environment values have been influencing them in this regards. 


\subsection{Objectives of the study}

Specific objectives of the study are:

1) To identify and examine the perceptions of Auditors and Accountants (CAs) on the level of acceptance and adherence to selected Indian accounting Standards issued by the ICAI.

2) To find out the differences among Auditors and Accountants (CAs) and analyse the impact of demographic and professional work environment related variables on acceptance and adherence to selected Indian accounting Standards as well as work values.

\section{Research methodology}

The quality of data is inextricably tied to the method and technique used for collection. Hence, survey method through structured questionnaire was adopted for this study, as it was found to be suitable for this research.

Sampling frame: - Primary data needed were collected through questionnaires issued to practicing auditors and professional accountants (CAs), who constitute the sample for the study. They represented a wide spectrum of CA firms/ corporate entities located mainly in Madras and some in different parts of Tamilnadu, India. Sample consists of Auditors who are either individuals or joint-partners of CA firms and professional accountants are CAs at different managerial levels like junior, middle and senior management categories. 'Purposive Judgment sampling' was adopted considering the availability and approachability of Auditors and Professional accountants for the purpose of data collection efforts.

Questionnaire design :- Questionnaires for sample survey of Auditors and Accountants were distributed among selected sample of Chartered accountants who were either practicing CAs (Auditors) or Professional CA';s (Professional accountants). A Sample of 307 respondents took part in the survey and it took approximately eleven months for distribution of questionnaires and collection of data from the respondents. The questionnaire used for data collection is a structured one, and it contains FIVE scales representing major variable Accounting Standards with 27 dimensions represented by selected Indian accounting standards, covered in 87 statements.

\section{Review of literature}

Many research studies attempt to relate perception on accounting standards from different perspectives.

Psaros, patel, \& warnakulasuriya (2003) had researched on Australian auditors' interpretation of selected key 'uncertainty expressions', such as virtual certainty, expected, reasonable assurance and possible outcomes, contained in Australian accounting and auditing standards, by a questionnaire survey study.[1] (Kanukuntla \& Rao, 2004), found that proper practice of accounting standards was very significant, as it led to the effective disclosure and consequently good corporate governance programs. Hence, the practice of proper accounting standards was more relevant issue of good corporate governance in the present competitive era as the standards provided a useful mechanism to restructure the core corporate values.[2] Haribhakti, (2008), had examined that the forces of globalization prompt more and more countries to open their doors to foreign investment and as businesses expand across borders, the need arises to recognize the benefits of having commonly accepted and understood financial reporting standards.[3]. H S Bajpayee, (2009), had researched that accounting standards had been and were being formulated at different levels. For different countries, the accounting standards were formulated by duly recognized and constituted authority keeping in mind the disclosure practices in India by Indian companies by dividing them into three levels as per the Institute of Chartered Accountants in India norms and further a questionnaire survey had been conducted to reach a conclusion that up to what extent Indian companies were complying with the Indian as well as international accounting standards.[4] Dr. Samiksha Ojha, (2012), had surveyed that Indian Banks were currently following the prudential norms of Reserve. The paper analyzed the impact of the new accounting system involving a major shift from prescriptive norms (based on accounting standards) to the system involving greater judgment. The paper elaborated the preparedness on Indian Banks to adopt the new accounting system, the challenges before it and the areas on which the banks must focus on to adopt the system. [5] Nyor,(2012), in his study recommended the adoption of the International Financial Reporting Standards by Nigerian companies in order for them to take advantage of the globalization effects.[6]

\section{Data analysis and interpretations}

Analysis of demographic profile and profession related characteristics of professional and practicing CAs.

The demographic and profession related characteristics reveal certain significant features of the sample respondents, which may be summarized as follows: 
Table 1: Table Showing the Demographic Profiles of Respondents

\begin{tabular}{|c|c|c|c|}
\hline No. & (2) & No. of Respondents & Percentages \\
\hline I & $\begin{array}{l}\text { AGE } \\
\text { Below } 30 \text { years } \\
30 \text { to } 40 \text { years } \\
40 \text { to } 50 \text { years } \\
\text { Above } 50 \text { years } \\
\text { Total }\end{array}$ & $\begin{array}{l}14 \\
80 \\
87 \\
126 \\
307\end{array}$ & $\begin{array}{l}4.6 \\
26.1 \\
28.3 \\
41.0 \\
100\end{array}$ \\
\hline II. & $\begin{array}{l}\text { GENDER } \\
\text { Male } \\
\text { Female } \\
\text { Total }\end{array}$ & $\begin{array}{l}262 \\
45 \\
307\end{array}$ & $\begin{array}{l}85.3 \\
14.7 \\
100\end{array}$ \\
\hline III. & $\begin{array}{l}\text { MARITAL STATUS } \\
\text { Single } \\
\text { Married } \\
\text { Total }\end{array}$ & $\begin{array}{l}14 \\
293 \\
307\end{array}$ & $\begin{array}{l}4.6 \\
95.4 \\
100\end{array}$ \\
\hline IV. & $\begin{array}{l}\text { FIELD OF SPECIALIZATION IN AUDITING } \\
\text { Tax Audit } \\
\text { Corporate Audit } \\
\text { Revenue Audit } \\
\text { Any other Audit } \\
\text { All the above } \\
\text { Total }\end{array}$ & $\begin{array}{l}80 \\
48 \\
19 \\
9 \\
151 \\
307\end{array}$ & $\begin{array}{l}26.1 \\
15.6 \\
6.2 \\
2.9 \\
49.2 \\
100\end{array}$ \\
\hline V. & $\begin{array}{l}\text { NO. OF YEARS EXPERIENCE IN THE FIELD } \\
\text { Less than } 5 \text { years } \\
5 \text { years to } 10 \text { years } \\
10 \text { years to } 15 \text { years } \\
\text { Above } 15 \text { years } \\
\text { Total }\end{array}$ & $\begin{array}{l}6 \\
77 \\
56 \\
168 \\
307\end{array}$ & $\begin{array}{l}2.0 \\
25.1 \\
18.2 \\
54.7 \\
100\end{array}$ \\
\hline VI. & $\begin{array}{l}\text { AVERAGE ANNUAL INCOME } \\
\text { Less than } 5 \text { lacs } \\
5 \text { lacs to } 10 \text { lacs } \\
10 \text { lacs to } 20 \text { lacs } \\
\text { Above } 20 \text { lacs } \\
\text { Total }\end{array}$ & $\begin{array}{l}39 \\
102 \\
85 \\
81 \\
307\end{array}$ & $\begin{array}{l}12.7 \\
33.2 \\
27.7 \\
26.4 \\
100\end{array}$ \\
\hline VII. & $\begin{array}{l}\text { CATEGORISATION OF RESPONDENTS } \\
\text { Professional Chartered accountants } \\
\text { Practicing Chartered accountants } \\
\text { Total }\end{array}$ & $\begin{array}{l}175 \\
132 \\
307\end{array}$ & $\begin{array}{l}57.0 \\
43.0 \\
100\end{array}$ \\
\hline VIII & $\begin{array}{l}\text { TYPE OF ORGANISATIONS-PROFESSIONAL CAs EMPLOYED } \\
\text { Private Sector (India) } \\
\text { Private Sector ( Multinational) } \\
\text { Government /Public Sector } \\
\text { Total }\end{array}$ & $\begin{array}{l}103 \\
62 \\
10 \\
175\end{array}$ & $\begin{array}{l}58.8 \\
35.0 \\
6.2 \\
100\end{array}$ \\
\hline IX & $\begin{array}{l}\text { FUNCTIONAL AFFILIATION OF PROFESSIONAL CAs } \\
\text { Accounts Dept } \\
\text { Finance Dept } \\
\text { Costing } \\
\text { Corporate } \\
\text { Any other } \\
\text { All the above } \\
\text { Total }\end{array}$ & $\begin{array}{l}22 \\
55 \\
10 \\
18 \\
9 \\
61 \\
175\end{array}$ & $\begin{array}{l}12.5 \\
31.3 \\
5.7 \\
10.2 \\
5.1 \\
35.2 \\
100\end{array}$ \\
\hline$X$ & $\begin{array}{l}\text { STRUCTURE OF CLIENT FIRM OF PRACTISING CAs } \\
\text { Individual } \\
\text { Partnership } \\
\text { Joint stock company } \\
\text { All the above } \\
\text { Total }\end{array}$ & $\begin{array}{l}36 \\
66 \\
3 \\
27 \\
132\end{array}$ & $\begin{array}{l}27.2 \\
50.0 \\
2.3 \\
20.5 \\
100\end{array}$ \\
\hline XI & $\begin{array}{l}\text { NATURE OF CLIENT BUSINESS OF PRACTISING CAs } \\
\text { Trading } \\
\text { Manufacturing } \\
\text { Service Industry } \\
\text { All the above } \\
\text { Total }\end{array}$ & $\begin{array}{l}23 \\
13 \\
5 \\
91 \\
132\end{array}$ & $\begin{array}{l}17.5 \\
9.8 \\
3.8 \\
68.9 \\
100\end{array}$ \\
\hline
\end{tabular}


Important demographic characteristics are presented below, based on the sample survey of professional and practicing CAs as shown in the above table.

1) Age group: $59 \%$ of the CAs are less than or equal to 50 years of age.

2) Gender: $85.3 \%$ of all CAs are males and $14.7 \%$ of all CAs are females.

3) Marital status: $95.4 \%$ (293) of the respondent CAs are married

4) Field of specialization: $49.2 \%$ have specialized in all three major types of audit namely Tax audit, corporate audit and Revenue audit.

5) Years of Experience: $72.9 \%$ have an experience of over 10 years in the field.

6) Annual Income: $73.6 \%$ have an average annual income below Rs.20 lakhs.

7) Categorization of CAs: Professional CAs and Practicing CAs $43 \%$.

8) Organization Employment: $93.8 \%$ of the Professional CA respondents are employed in Private sector Organizations.

9) Functional affiliation: $35.2 \%$ of the Professional CAs have functional affiliation to all four major functions of accounts, finance, costing and corporate affairs.

10) Client Organization structure: Of the practicing CAs' $27.3 \%$ have clients' as sole proprietors, $50 \%$ have clients' firm -partnership and 2.3\% have clients' of joint stock company and $20.5 \%$ have clients' in all three forms.

11) Nature of client business: Of the practicing CAs' $17.4 \%$ have clients' of trading, $9.8 \%$ have clients' of manufacturing, $3.8 \%$ have clients' of service industry and $67.4 \%$ have clients' in all three types of businesses.

Classification based on mean score for respondent perceptions of accounting standards.

Table 2: Showing the Perceptions of Accounting Standards Based on Mean Score

\begin{tabular}{|c|c|c|c|c|}
\hline Accounting Standard & Description & Mean & Rank & Remarks \\
\hline $\mathrm{AS}-26$ & Intangible assets Reporting & 73.6482 & 1 & $\mathrm{AA}$ \\
\hline AS-28 & Impairment of Assets & 71.4658 & 2 & AA \\
\hline AS-3 & Cash flow statements & 71.4007 & 3 & AA \\
\hline AS-2 & Valuation of Inventories & 70.5972 & 4 & $\mathrm{AA}$ \\
\hline AS-27 & Financial Reporting of Interest in JVs & 69.1422 & 5 & $\mathrm{AA}$ \\
\hline AS-13 & Accounting for Investments & 69.0771 & 6 & $\mathrm{AA}$ \\
\hline AS-29 & Accounting. for Provisions, Contingent Liabilities \& assets & 68.8599 & 7 & $\mathrm{AA}$ \\
\hline AS-17 & Segment reporting & 68.4256 & 8 & AA \\
\hline AS-18 & Related party disclosures & 67.7307 & 9 & AA \\
\hline AS-1 & Disclosure of accounting policies & 67.5733 & 10 & AA \\
\hline AS-12 & Accounting for Govt. Grants & 67.2964 & 11 & $\mathrm{AA}$ \\
\hline AS-15 & Accounting for employee benefits & 66.8621 & 12 & AA \\
\hline AS-19 & Accounting for Leases & 66.7752 & 13 & $\mathrm{AA}$ \\
\hline AS-9 & Revenue Recognition in the books & 66.645 & 14 & $\mathrm{AA}$ \\
\hline AS-21 & Consolidated Financial Statements & 66.4061 & 15 & $\mathrm{AA}$ \\
\hline AS-16 & Accounting for Borrowing costs & 66.1455 & 16 & $\mathrm{AA}$ \\
\hline $\mathrm{AS}-25$ & Interim Financial Reporting & 65.8198 & 17 & $\mathrm{BA}$ \\
\hline AS-24 & Discontinuing Operations & 64.582 & 18 & BA \\
\hline $\mathrm{AS}-4$ & Contingencies \& post balance sheet events & 63.8654 & 19 & BA \\
\hline AS-7 & Construction contract accounting & 63.6048 & 20 & BA \\
\hline AS-30 & Accounting for Financial Instruments & 63.3388 & 21 & BA \\
\hline AS-22 & Accounting for taxes on income & 62.1716 & 22 & BA \\
\hline AS-5 & Prior period items \& change in accounting policies & 61.987 & 23 & $\mathrm{BA}$ \\
\hline AS-23 & Accounting for investment in associate Co’s. & 61.3518 & 24 & BA \\
\hline AS-14 & Accounting for amalgamations & 60.76 & 25 & BA \\
\hline AS-20 & Computation of Earnings per share & 59.9131 & 26 & BA \\
\hline AS-11 & Effects of changes in Foreign Exchange Rates & 59.2157 & 27 & $\mathrm{BA}$ \\
\hline
\end{tabular}

AA: Above average

BA: Below average

The ranking of accounting standards on the basis of mean-score values indicate the following results:-

i) The average of the mean-score value is 66.098. Of the 27 standards taken for the study 16 standards have the mean score above the average mean score with their combined average of 68.628 and 11 standards whose average is below the average mean-score, their combined average is 62.725 .

ii) The ranking of accounting standards on the basis of the value of mean score indicate the following top-5 ranked accounting standards':

Accounting standards

AS-26 (Intangible assets) 
$\begin{array}{ll}\text { AS-28 (Impairment of assets) } & 71.466 \\ \text { AS-3 (Cash-flow statement) } & 71.400 \\ \text { AS-2(Valuation of inventory) } & 70.597 \\ \text { AS-27(Financial Reporting of Interest in JVs) } & 69.142\end{array}$

The respondents high mean-value score for the above standards indicate that are presumed to be the most remembered and used accounting standards by the CAs in their professional career.

iii) Similarly the following are the accounting standards with least mean-score values:

Accounting standards

AS-11 (Effects of changes in F/Exch. rates)

AS-20 (Computation of EPS)

AS-14 (Accounting for amalgamation)

AS-23 (Accounting for investment in associate Co's.)

AS-5 (Prior period items/change in a/c policies) $\underline{\text { mean score }}$

59.215

59.913

60.760

61.351

61.351

The respondents' low mean-value score for the above standards indicate that are presumed to be the least remembered and used accounting standards by the CAs in their professional career.

Analysis of perception on accounting standards based on demographic variables

Personal characteristics are likely to influence the perceptions on accounting standards of the CAs. Hence, by applying ANOVA ( $F$ test), the differences in levels of accounting standards among the CAs are tested on the basis of selected demographic variables. The results and their significance are explained below.

Table 3: Analysis of Perception on Accounting Standards Based on Demographic Variables

\begin{tabular}{lllll}
\hline Variable & Mean Value & F- Value & P- Value & Level of Significance \\
\hline Age & 65.01 & 3.629 & $.000^{* *}$ & Significant \\
Gender & 65.13 & 1.072 & .301 & .246 \\
Marital Status & 66.86 & 1.349 & .240 & Not-Significant \\
Field of specialization in Auditing & 66.15 & 1.969 & $.000^{* *}$ & Not-Significant \\
Years of experience & 66.00 & 3.050 & $.000^{* *}$ & Significant \\
Annual Income & 65.46 & 2.318 & $.000^{* *}$ & Significant \\
Nature of work & 65.81 & .307 & .580 & Significant \\
CAs' employment Organization type & 68.39 & 1.777 & $.004^{* *}$ & Not-Significant \\
functional affiliation & 66.17 & 1.523 & $.025^{*}$ & Significant \\
type of client organization & 65.36 & 1.734 & $.014^{*}$ & Significant \\
type of client business & 67.44 & 3.315 & $.000^{* *}$ & Significant \\
& & & Significant
\end{tabular}

Source: Primary data

** Highly Significant at $1 \%$ Level.

* Significant at $5 \%$ Level.

\section{Findings}

1) With the advancement of age, individual's perceptions towards the accounting standards show a significantly higher level among CAs.

2) Male and female CAs are high in their perception on accounting standards and irrespective of the gender, they are not significantly different in their perceptions on accounting standards.

3) Single and married CAs were high in their perception on accounting standards and they are not significantly different in their perceptions on accounting standards. But single status respondents being younger in age than married respondent, by means of their acquaintance with updates on accounting standards shows marginally higher mean value in the perception than married group.

4) CAs grouped and analyzed on the basis of field of specialization in auditing exhibit a high levels of perception and shows significantly different perceptions towards accounting standards.

5) CAs with less than 10 years of experience shows decreasing level of the means as compared to CAs' with more than 10 years of experience and in general shows significantly different perceptions towards accounting standards.

6) The mean scores show that higher the income level, higher will be the level of awareness and so higher the level of perception on accounting standards.

7) A high levels of perception on accounting standards among the group of Professional CAs as compared to the group of Practicing CAs., and both groups show not-significantly different perceptions towards accounting standards.

8) A high levels of perception on accounting standards among the CAs employed with Govt. / Public sector undertakings as compared to the other type Organizations where professional CAs are employed in general show significantly different perceptions towards accounting standards. 
9) CAs grouped and analyzed on the basis of functional affiliation, those who are affiliated to the function of Corporate-accounts and Accounts in general exhibit a high levels of perception on accounting standards and CAs who are affiliated to all functions like finance/accounts/corporate accounts generally exhibit low level of perception towards accounting standards as compared to those who are affiliated to any one of the functions. Also CAs, being classified on basis of the functional affiliation in the organization employed in general show significantly different perceptions towards accounting standards.

10) CAs' perceive that accounting standards are more adhered and followed by joint stock companies and partnership firms than sole-proprietor firms and CAs who are affiliated to clients with all types of organization generally exhibit low level of perception towards accounting standards as compared to those who are affiliated to any one of the type of client organization structure and in general show significantly different perceptions towards accounting standards.

11) CAs affiliated to the clients in trading and Service industry adhere and follow accounting standards as compared to manufacturing firms. Also Professionals CAs, being classified on basis of the client in general business show significantly different perceptions towards accounting standards.

\section{Implications of the study}

The study focuses on the differential perceptions of professional and practicing CAs which imply the following revelations.

a) CA's 'age' is an important factor influencing the perception on accounting standards of CAs, as normally a person's perception and emotional intelligence level first increase with the age and reach at a peak and then start decreasing, as suggested in many researches.

b) Irrespective of the gender group, the adherence to accounting standards roles are mandatory for professional and practicing CAs.

c) CAs with different years of experience in auditing in general shows significantly different perceptions towards accounting standards.

d) CAs with different range on annual income in general shows significantly different perceptions towards accounting standards.

e) The high mean value between professional and practicing CAs shows that both groups were having good knowledge on accounting standards and there is no significant difference in the same. But the relative knowledge varies depending upon the type of organization the employed in.

f) The reason for the varying level of perception when the respondents were classified on basis of functional affiliation was due to the different type of job assignments handled and difference in the departments and its policies.

g) CA's perceptions were influenced by nature of the client organization and type of firm-structure and its policies and hence the existence of the Level of significance being significant. Thus for the knowledge of Accounting Standards the type of their client organization influence was substantial.

h) When the respondents, being professional CAs were classified on basis of their organization type, their perceptions were influenced by nature of the organization and type of business carried over and its policies and hence the existence of the Level of significance being significant.

\section{Discussion}

(Personal opinion summary of CAs)

Further, summarized general observations of sample respondent CAs on the Indian Accounting Standards, professional code of conduct and ethical work life etc., and their expectations are given below.

Sample respondent CAs expect on accounting standards:-

- Practical adoptability of accounting standards required very much among the professional.

- Uniform accounting standards must result in uniform accounting practices

- Accounting standards some-what difficult to follow- (It could be due to interpretation of the rules)

- Accounting standards are useful to professional CAs, especially those who apply them in their entities.

- $\quad$ Practical adoptability of accounting standards is possible only with active participation of all concerned

- $\quad$ Absolutely mandatory, must achieve 100\% IFRS

- In-depth knowledge is called for on the part of companies to ensure greater compliance

- Calls for lot of adoptable and convergence efforts.

- $\quad$ Accounting standards are objective- opinion differs

- $\quad$ Requires lot of awareness and support at the top management and training for the employees in the clients' entity for proper appreciation and preparation of accounts as per GAAP

- $\quad$ Medium and small firms need to be sensitized and made aware of these standards and their importance.

- Interpretation and practical application warrants clear understanding of the basic principles, for which AS have been developed. 
- $\quad$ Most of the accounting standards are adopted well in companies.

- $\quad$ For small enterprises, a separate set of standards ought to be evolved after through research especially after taking into account the views of CAs in mofussil areas.

- Some standards such as the ones on financial instrument may not always be practical.

- Miles to go! As the objective of accounting standards was to bring uniformity, which according to me has not been obtained. The users of financial statements find it difficult to actually get clear picture of the financial statements especially the ones who have les knowledge about accounting.

- $\quad$ Accounting standards are well researched and well thought of, must be adhered to at all times.

\section{Conclusion and recommendations}

ICAI must develop different strategies to comply with the issues related to 'accounting rules and standards' and compliance with 'professional code of conduct 'related aspirations of the member CAs based on their performance effectiveness and their needs. But this should be preceded by a good, positive and conducive work environment both for professional and practicing CAs and recognition of their functional, emotional and managerial competency related problems, immediate addressing of their grievances and difficulties by providing better opportunities and forum to express the same will certainly keep them develop more their faith and practice of better adherence to the accounting standards and more vigorous compliance with professional code of conduct..

For this purpose, more innovative programs are to be implemented by ICAI like:-

a. Corporate Governance transparency, through information technology

b. More interactive training sessions especially covering attitude studies for member CAs in well conducted workshops and seminars on Systematic problem solving techniques, case study analysis and exposure to modern auditing practices and develop more ethical based client relationships.

c. ICAI should establish ethics departments to ensure that activities adhere to the codes of ethics including the financial reporting process, accountants and accounting officers in corporate entities and practicing auditors should adhere to the International Financial Reporting Standards (IFRS) in the reporting structure to reduce the failure symptoms in the industry.

\section{Specific suggestion of auditors}

Practical observations made by CAs in the survey (related to accounting standards) reveal the following:-

- Uniform accounting standards must result in uniform accounting practices.

- Practical adoptability of accounting standards is possible only with active participation of all concerned,

- Awareness and support at the top management and training for the employees in the clients' entity for proper appreciation and preparation of accounts as per GAAP is required.

- Medium and small firms need to be sensitized and made aware of these standards and their importance.

- $\quad$ For small enterprises, a separate set of standards ought to be evolved after through research especially after taking into account the views of CAs in mofussil (suburb) areas.

- Accountancy profession has high public value.

To conclude, it shall be stated that, perceptions of CAs on accounting standards and professional ethics need not be viewed as independent elements, but are composite in nature. Both are affected by the factors of work environment and professional commitment like work values and how the management personnel view their experiences in work life situations and in respective work organizations. The study highlights that work environment and professional work values together with the chances to achieve professional excellence in organizations influence the level of adherence to accounting standards and compliance with professional code of ethical conducts. On the basis of the findings, the study concluded that ethical accounting standards are fundamentally necessary for accountants to produce quality financial reports free from material misstatements.

\section{Scope for future research}

More behavioral studies are needed to understand the accounting standards and professional ethical aspects and related perceptions of CAs, both auditors and accountants. More studies related to professional ethical practices of corporate professional accountants, the impact of dimensions of organizational structure and culture dimensions such as formalization and centralization etc., must be made. Replicate studies also will be necessary to establish the generalizability of the present results. Relevance of perception on accounting standards phenomena can also be studied in relation to specific organizations and/or specific functional group of CAs, in addition to demographic and structural relationships. Research studies exclusively on women CAs and professionals in corporate organizations to probe ethical code of conduct compliance integrating their achievement of professional potential goal and value needs are also 
important, as a growing number of women are found in many specialized functional disciplines like finance, auditing, corporate and management accounting legal, secretarial and banking etc.,

\section{Acknowledgement}

The Authors jointly express their acknowledgement to Dr. (Prof).K.Sankaran (Retd) Head-Department of Commerce, D. B. Jain College, Chennai, India for sharing his valuable time to guide the researcher in the course of the entire study. The support given be the Chartered Accountants attached to the ICAI Chapters of Chennai, Madurai and other chapters of Tamilnadu-India for actively taking part in the survey is deeply appreciated.

\section{References}

[1] Psaros, J., patel, c., \& warnakulasuriya, S. (2003, December). A study of uncertainty expressions in Australian Accounting and auditing Standards. Pacific Accounting Review, Vol.15(No.2).

[2] Kanukuntla, S., \& Rao, D. N. (2004). Corporate Governance and Accounting Standards in India: An Empirical Study on Practices. SSRN Working Paper Series. http://dx.doi.org/10.2139/ssrn.501242.

[3] Haribhakti, S. (2008, July). Financial accounting standards: Convergence of Indian standards with the global standards. International Journal of Disclosure and Governance, 272-283. http://dx.doi.org/10.1057/jdg.2008.12.

[4] H S Bajpayee, A. S. (2009). Accounting Standard Disclosure Compliance in Online Reporting by Indian Companies. The IUP Journal of Accounting Research, VIII (2009)(1 (January)), 45-66. Retrieved May 15, 2015

[5] Dr. Samiksha Ojha, D. D. (2012, September). Accounting Globalization: Issues and Challenges of IFRS Implementation in Indian. Research Journal of Economics \& Business Studies, vol.1(no.11), 47-53. Retrieved May 10, 2015, from https://www.theinternationaljournal.org/ojs/full/vol01no11_rjebs.pdf

[6] Nyor, T. (2012, August). Expected Benefits of Implementing Global Accounting Standards by Nigerian Business Entities. International Journal of Business and Management, Vol. 7, (No. 15), 98-104. http://dx.doi.org/10.5539/ijbm.v7n15p98. 